\title{
Photobiomodulation in Sciatic Nerve Crush Injuries in Rodents: A Systematic Review of the Literature and Perspectives for Clinical Treatment
}

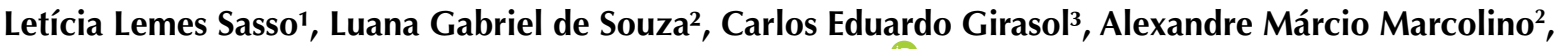 \\ Rinaldo Roberto de Jesus Guirro ${ }^{3}$, Rafael Inácio Barbosa ${ }^{2,3 *}$ \\ ${ }^{1}$ Department of Health Sciences, Federal University of Santa Catarina/UFSC - Araranguá, Brazil \\ ${ }^{2}$ Postgraduate Program in Rehabilitation Sciences, Federal University of Santa Catarina / UFSC - Araranguá, Brazil \\ ${ }^{3}$ Postgraduate Program in Rehabilitation and Functional Performance, University of São Paulo/USP - Ribeirão Preto, Brazil
}

\author{
*Correspondence to \\ Rafael Inácio Barbosa, Ph.D. \\ Laboratory of Assessment and \\ Rehabilitation of Locomotor \\ System, Federal University of \\ Santa Catarina (LARAL / UFSC) \\ Rua Pedro João Pereira, 150. CEP \\ 88905-120, Araranguá, Santa \\ Catarina, Brazil. \\ Tel: +55 48 9688-7711 \\ Email: rafael.barbosa@ufsc.br
}

Published online June 21, 2020

\begin{abstract}
Objective: The aim of the study was to perform a literature review to analyze the effect of photobiomodulation in experimental studies on peripheral nerve regeneration after sciatic nerve crush injury in rodents.

Methods: A bibliographic search was performed in the electronic databases, including MEDLINE (PubMed), SCOPUS, and SciELO, from 2008 to 2018.

Results: A total of 1912 articles were identified in the search, and only 19 fulfilled all the inclusion criteria. Along with the parameters most found in the manuscripts, the most used wavelengths were $660 \mathrm{~nm}$ and $830 \mathrm{~nm}$, power of 30 and $40 \mathrm{~mW}$, and energy density of 4 and $10 \mathrm{~J} / \mathrm{cm}^{2}$. For total energy throughout the intervention period, the lowest energy found with positive effects was $0.70 \mathrm{~J}$, and the highest $1.141 \mathrm{~J}$. Seventeen studies reported positive effects on nerve regeneration. The variables selected to analyze the effect were: Sciatic Functional Index (SFI), Static Sciatic Index (SSI), morphometric, morphological, histological, zymographic, electrophysiological, resistance mechanics and range of motion (ROM). The variety of parameters used in the studies demonstrated that there is yet no pre-determined protocol for treating peripheral nerve regeneration. Only two studies by different authors used the same power, energy density, beam area, and power density. Conclusion: It was concluded that the therapeutic window of the photobiomodulation presents a high variability of parameters with the wavelength (632.8 to $940 \mathrm{~nm}$ ), power (5 to $170 \mathrm{~mW}$ ) and energy density (3 to $280 \mathrm{~J} / \mathrm{cm}^{2}$ ), promoting nerve regeneration through the expression of cytokines and growth factors that aid in modulating the inflammatory process, improving morphological aspects, restoring the functionality to the animals in a brief period.

Keywords: Phototherapy; Nerve regeneration; Sciatic nerve; Experimental studies; Injury; Lasers and light sources.
\end{abstract}

\section{Introduction}

Peripheral nerves are structures that suffer lesions similar to those observed in other tissues, resulting in motor and sensory deficits. The causes of peripheral nervous system (PNS) injuries include traumatic and non-traumatic injuries such as complete or partial crushing. These lesions can damage the integrity of the tissue, causing important dysfunctions in the innervated structures, resulting in loss or reduction of sensation and motor activity with significant consequential alterations in the nerve pathway and axonal transport. If the injury is not adequately treated, it can cause a considerable deficit, with damage not only to the patients' quality of life but also to the state system in the cases of premature retirement due to functional disability. ${ }^{1-5}$

Twenty million Americans suffer from peripheral nerve damage caused by traumatic injuries. Nerve injuries result in approximately $\$ 150$ billion of annual health dollars spent in the United States. ${ }^{6}$ In Brazil, a recent study classified 456 cases of nerve damage and showed that axonotmesis represents the most common nerve injury (45\%) followed by neurotmesis $(41 \%)$ and neuropraxia (14\%) respectively. ${ }^{7}$

Seddon classified PNS lesions as neuropraxia, axonotmesis, and neurotmesis. ${ }^{4}$ Sunderland refined Seddon's classification by dividing it into five degrees. ${ }^{6}$ Nerve crush injury is a common type of injury that results in axonal interruption with the preservation of 
nerve support structures (conjunctive sheaths), called axonotmesis. ${ }^{2,5,6,8}$

After a peripheral nerve injury, distally located axons and myelin sheaths degenerate and undergo the action of Schwann cells and macrophages, which through Wallerian degeneration will degrade the entire axon structure, providing a favorable environment for new axonal growth. ${ }^{9}$

The sciatic nerve of rodents is a reliable model for studying crush injury because it causes the rupture of nerve fibers without the rupture of most nerve supporting structures, which facilitates regeneration after the injury. The macroscopic analysis of the crushed nerve with the adjustable tweezers shows the same aspect of the lesion produced with the dead weight and tensile strength machines. The analysis of the Sciatic Functional Index (SFI) indicates that the degree of functional impairment through compression with the adjustable tweezers is compatible with that observed in similar lesions produced with the dead weight and tensile strength machines for the same injury load. ${ }^{10}$

Sciatic nerve repair leads, as a general rule, to the development of neuropathic pain in rodents, manifested by an abnormal response to thermal and tactile stimuli, being an advantage of the experimental model, since neuropathic pain is a common consequence of nerve damage in humans. The severity of the crush injury is directly related to the magnitude, duration, and mechanism of the compressive trauma, so it is necessary to standardize the type of injury to reduce the risk of bias in the experimental research. The sciatic nerve injury model is undoubtedly an important and valuable experimental model, and to date, its use in rodents has provided the most data on peripheral nerve regeneration. ${ }^{11}$

Different experimental studies have used photobiomodulation as a treatment for peripheral nerve injury in rodents to optimize the regeneration of the sciatic nerve after crush injury. ${ }^{5,8,12-14}$ The restoration of nerve activity is an effect of photobiomodulation, a physical medium with a prominent level of positive response with $80 \%$ efficacy. ${ }^{12}$ The effects of photobiomodulation at the cellular level can induce trophic conditions and inhibit the inflammatory processes necessary for nerve regeneration. ${ }^{15}$ Photobiomodulation improves the production of adenosine triphosphate (ATP), gene expression, and the secretion of neural factors. ${ }^{5,15}$

Current studies show that the absorption of photons by cytochrome $\mathrm{C}$ oxidase in the mitochondrial respiratory chain is the main event that initiates photobiomodulation. Increased cytochrome $\mathrm{C}$ oxidase activity increases the production of ATP, which in wounds or areas with low blood perfusion can activate damaged cells and metabolic disorders. Photon energy can modulate reactive oxygen species, activate mitochondrial DNA replication, increase early-response genes, and the expression of the growth factor, induce cell proliferation, and alter nitric oxide levels., ${ }^{5,16}$ However, conflicting results are frequently observed, most likely due to the significant variation of the parameters used by different researchers, such as the wavelength, irradiation type, doses, and energy density. ${ }^{5,12,16}$ Despite a large number of experimental studies in this area of knowledge, there is still a small number of clinical studies reporting these results in humans.

The present study aimed to analyze the effect of photobiomodulation therapy on peripheral nerve regeneration after sciatic nerve crush injury in experimental studies.

\section{Methods}

Research Strategy

A literary search was conducted as recommended by

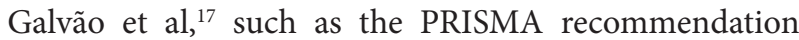
for systematic reviews and meta-analysis. The search for scientific articles was conducted by two independent researchers in the electronic databases, including MEDLINE (PubMed), SCOPUS, and SciELO, from August 2016 to October 2018. The search was based on the words from the Medical Subject Heading Terms (MeSH) dictionary, descriptors, and Boolean operators. The first search was performed in the PubMed database according to the combinations of the following words: (animals; laser therapy; low-level light therapy; laserbiostimulation; low-level laser therapy; peripheral nerve injuries; nerve regeneration; sciatic nerve). The search in the subsequent bases had adjustments according to when it was necessary.

\section{Criteria for the Selection of Studies}

The present review included experimental studies using photobiomodulation (low-level laser therapy [LLLT] and LED) in peripheral nerve regeneration after sciatic nerve crush injury in rodents, published in the last ten years, in English and Portuguese. The following studies were excluded: the studies published before 2008, those who used other electrophysical resources, literature reviews, systematic reviews or meta-analyses, clinical studies (in vivo), and those published in the form of abstracts. Subsequently, the articles that used other animals as study subjects (in vivo) and were not published in English or Portuguese were restricted.

\section{Data Analysis}

Two independent researchers analyzed the search results to find potentially eligible studies. Initially, the articles were excluded according to duplicated titles and inappropriate titles, then the abstracts were analyzed, and only those that were potentially eligible were selected. Based on the abstracts, articles were selected for full reading, leaving only those that met all pre-determined criteria. In case of disagreement between evaluators, a third evaluator decided on the eligibility of the study in 
question. The review process is seen in Figure 1.

\section{Results}

A total of 1912 articles were identified in the search. After the exclusion of articles published as systematic reviews, duplicated titles, inadequate titles, and abstracts, 30 articles were selected for a complete review, and only 19 articles fulfilled all the inclusion criteria. Among these articles, we highlight that the most used wavelengths were 660 $\mathrm{nm}^{1,2,7,18-20}$ and $830 \mathrm{~nm},{ }^{2,12,21,22}$ the powers were $30^{2,18,19,21,22}$ and $40 \mathrm{~mW}^{5,7}$ and the energy densities were $4^{1,3,5,23}$ and $10^{2,5,7,13,16,19,21} \mathrm{~J} / \mathrm{cm}^{2}$. Tables $1-3$ describe the experimental design used in the studies selected for this review and the parameters of the LLLT and LED. Seventeen studies reported positive effects in favor of photobiomodulation on nerve regeneration.

The variables selected to analyze the effect of photobiomodulation were: SFI, Static Sciatic Index (SSI), morphometric, morphological, histological, zymographic, electrophysiological, resistance mechanics, and range of motion (ROM).

Table 4 shows the models of lesions of the sciatic nerve injury used by the authors in their studies; they are as follows: a deadweight machine, , $5,13,19,21,22$ calibrated adjustable tweezer, ${ }^{12,} 24$ homeostatic tweezer, ${ }^{1,3,14,23,25,26}$ and non-serrated homeostatic tweezer. ${ }^{8,7,20,27}$ The literary review showed consistent and significant results in favor of photobiomodulation about sciatic nerve regeneration after crush injury, as shown in Table 5.

Based on the results found in the 19 articles, only two studies $^{7,25}$ did not present significant results on the effects of photobiomodulation on sciatic nerve regeneration. The variety of parameters used in the studies demonstrated that there is yet no pre-determined protocol for treating peripheral nerve regeneration. Based on these findings, it was assumed that the therapeutic window of the photobiomodulation is wide, presenting a high variability of parameters. Only two studies ${ }^{1,3}$ by different authors used the same power, energy density, beam area, and power density.

Thus, the 19 manuscripts included in the study present a therapeutic window for intensity varying from $0.1 \mathrm{~J}$ to $57.05 \mathrm{~J}$ at each point per intervention day. For total energy throughout the intervention period, the lowest energy found with positive effects was $0.70 \mathrm{~J}$ and the highest 1.141 J. Still, it is essential to highlight the intervention period employed between each protocol of the included studies. For the highest total energy, 20 days of intervention were performed and for the smallest, only seven days. Therefore, the protocols covered a variety of intervention times, being two days ( 1 study), 6 days ( 1 study), 7 days (2 studies), 10 days ( 1 study), 14 days (4 studies), 20 days (2 studies), 21 days (9 studies) and 28 days (1 study) (Figure 2).

Finally, it is important to determine such parameters for better clinical use for the regeneration process after a peripheral nerve injury. Andreo et $\mathrm{al}^{28}$ pointed out that most of the studies of their review used a power of up to $50 \mathrm{~mW}$ and total energy of up to $15 \mathrm{~J}$ administered in multiple points, so among the 31 protocols with positive results, only seven studies would be within or close to this power window (5 J above or below this value), and 23 protocols have a power of up to $50 \mathrm{~mW}$.

\section{Discussion}

Different studies included in this review show consistently positive results on the effect of photobiomodulation on nerve regeneration. The benefits resulting from photobiomodulation may include vasodilation and proliferation of microvessels, with possible increase in the amount of tissue oxygen, epithelial proliferation, endothelial and fibroblast, increase of collagen synthesis and phagocytic activity, resulting in the acceleration of the repair process in addition to the release of cytokines that reduce the inflammatory reaction. The response to photobiomodulation depends directly on the wavelength,

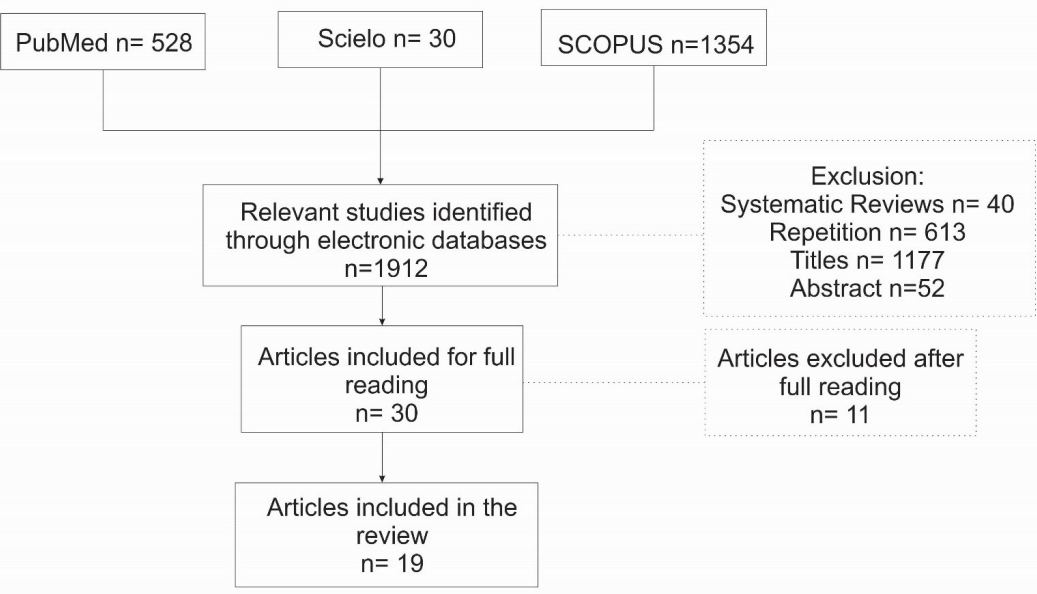

Figure 1. Flowchart of the Search and Analysis of Articles 
Table 1. Experimental Design of the Studies - Part 1

\begin{tabular}{|c|c|c|c|c|c|c|c|}
\hline & $\begin{array}{c}\text { Belchior et al, } \\
20091\end{array}$ & $\begin{array}{c}\text { Barbosa et al, } \\
2010^{2}\end{array}$ & $\begin{array}{c}\text { Barbosa et al, } \\
2010^{18}\end{array}$ & $\begin{array}{c}\text { Gigo-benatto et al, } \\
2010^{7}\end{array}$ & $\begin{array}{c}\text { Gonçalves et al, } \\
2010^{24}\end{array}$ & $\begin{array}{l}\text { Marcolino et } \\
\text { al, } 2010^{21}\end{array}$ & $\begin{array}{c}\text { Câmara et al, } \\
2011^{3}\end{array}$ \\
\hline Positive effect & YES & YES & YES & NO & YES & YES & YES \\
\hline Sample & 12 Wistar rats & 27 Wistar rats & 18 Wistar rats & 64 Wistar rats & 20 Wistar rats & 18 Wistar rats & 20 Wistar rats \\
\hline Division of groups & CG, LG & $\begin{array}{c}\text { Sham, LG }(660 \\
\mathrm{nm}), \text { LG }(830 \\
\mathrm{nm})\end{array}$ & CG, LG & $\begin{array}{c}\text { CG, NI, G }(660 \mathrm{~nm} / 10 \\
\text { J), LG }(660 \mathrm{~nm} / 60 \mathrm{~J}) \text {, } \\
\text { LG }(660 \mathrm{~nm} / 120 \mathrm{~J}) \text {, } \\
\text { LG }(780 \mathrm{~nm} / 10 \mathrm{~J}), \mathrm{LG} \\
(780 \mathrm{~nm} / 60 \mathrm{~J}), \mathrm{LG}(780 \\
\mathrm{nm} / 120 \mathrm{~J})\end{array}$ & $\begin{array}{c}\text { P (7 days), } \mathrm{P} \\
\text { (14 days), LG (7 } \\
\text { days), } \mathrm{LG}(14 \\
\text { days })\end{array}$ & Sham, LG & $\begin{array}{l}\text { CG }(14 \text { days), } \\
\text { CG }(21 \text { days), } \\
\text { LG }(14 \text { days), } \\
\text { LG }(21 \text { days), }\end{array}$ \\
\hline $\begin{array}{l}\text { Number of points } \\
\text { treated }\end{array}$ & $\begin{array}{l}\text { Multiple points } \\
\text { (3) }\end{array}$ & 1 point & 1 point & Multiple points (2) & 1 point & 1 point & $\begin{array}{c}\text { Multiple points } \\
(6)\end{array}$ \\
\hline Days of application & 20 & 21 & 21 & 10 & 7 and 14 & 21 & 14 and 21 \\
\hline $\begin{array}{l}\text { Total of energy } \\
\text { emitted (J)/Total of } \\
\text { energy per day }\end{array}$ & $50.80 * / 2.54^{*}$ & $\begin{array}{l}12.60 * / 0.60 \\
24.15 * / 1.15\end{array}$ & $12.60 * / 0.60$ & $\begin{array}{c}40 * / 4 * *, 240^{*} / 24^{* *} \\
480^{*} / 48^{* *}\end{array}$ & $\begin{array}{l}0.84 * / 0.12 \\
1.68 * / 0.12\end{array}$ & $97.44 * / 4.64$ & $\begin{array}{l}11.76 * / 0.84 * \\
17.64 * / 0.84 *\end{array}$ \\
\hline $\begin{array}{l}\text { Treatment time per } \\
\text { point (s) }\end{array}$ & 96.70 & $20,38,66$ & 20 & $18,60,120$ & 4 & $154^{*}$ & 32 \\
\hline Beam Area $\left(\mathrm{cm}^{2}\right)$ & 0.63 & $0.06,0.11$ & 0.06 & 0.04 & 0.62 & 0.11 & 0.63 \\
\hline $\begin{array}{l}\text { Power Density (W/ } \\
\mathrm{cm}^{2} \text { ) }\end{array}$ & 0.04 & $0.5^{*}, 0.25^{*}$ & $0.5^{*}$ & $1^{*}$ & $0.04 *$ & $0.25^{*}$ & 0.04 \\
\hline $\begin{array}{l}\text { Energy Density (J/ } \\
\left.\mathrm{cm}^{2}\right)\end{array}$ & 4 & 10 & 10 & $10,60,120$ & 4 & 40 & 4 \\
\hline Power (mW) & 26.3 & 30 & 30 & 40 & 30 & 30 & 26.3 \\
\hline Wavelength (nm) & 660 & 660,830 & 660 & 660,780 & 830 & 830 & 904 \\
\hline Light source & $\begin{array}{l}\text { Laser (CW) - } \\
\text { GaAlAs }\end{array}$ & $\begin{array}{l}\text { Laser (CW) - } \\
\text { GaAlAs }\end{array}$ & $\begin{array}{l}\text { Laser }(\mathrm{CW}) \text { - } \\
\text { GaAlAs }\end{array}$ & Laser (CW) - GaAlAs & Laser (CW) & $\begin{array}{l}\text { Laser (CW) - } \\
\text { GaAlAs }\end{array}$ & $\begin{array}{l}\text { Laser (PW) - } \\
\text { GaAs }\end{array}$ \\
\hline
\end{tabular}

Abbreviations: LG (Group LLLT), LEDG (Group LED), Sham (control + crush), CG (Control group), NI (nerve injury), P (placebo), Dex (dexamethasone), GaAlAs (Gallium- Aluminized-Arsenide), LED (light-emitting diode), InGaAIP (Phosphate of Arsenic Indium Gallium).

*means that the original article does not show the parameter, but was calculated; ${ }^{* *}$ means that the article does not present the parameters consistently.

Table 2. Experimental Design of the Studies - Part 2

\begin{tabular}{|c|c|c|c|c|c|c|}
\hline Author & $\begin{array}{l}\text { Tomazini et al, } \\
2011^{25}\end{array}$ & $\begin{array}{l}\text { Gomes et al, } \\
2012^{26}\end{array}$ & Serafim et al, $2012^{23}$ & $\begin{array}{l}\text { Alcântara et al, } \\
{2013^{27}}^{27}\end{array}$ & $\begin{array}{l}\text { Marcolino et al, } \\
2013^{22}\end{array}$ & $\begin{array}{l}\text { Akgul et al, } \\
2014^{13}\end{array}$ \\
\hline Positive effect & No & Yes & Yes & Yes & Yes & Yes \\
\hline Sample & 16 Swiss rats & 36 Wistar rats & 40 Wistar rats & 30 Wistar rats & 36 Wistar & 30 Wistar rats \\
\hline Division of groups & $\begin{array}{l}\text { CG, NI, LG } \\
(\mathrm{HeNe}), \text { LG (AsGa) }\end{array}$ & $\begin{array}{l}\text { CG, LG (7 } \\
\text { days), LG ( } 14 \\
\text { days), LG ( } 21 \\
\text { days) }\end{array}$ & $\begin{array}{l}\text { CG, NI, LEDG, CG } \\
+ \text { LED }\end{array}$ & CG, Sham, LG & $\begin{array}{l}\text { Sham, LG }(10 \mathrm{~J} / \\
\left.\mathrm{cm}^{2}\right), \mathrm{LG}(40 \mathrm{~J} / \\
\left.\mathrm{cm}^{2}\right), \mathrm{LG}(80 \mathrm{~J} / \\
\left.\mathrm{cm}^{2}\right)\end{array}$ & $\begin{array}{l}\text { CG, LG (14 days } \\
\text { continuous), LG } \\
\text { (after seven days) }\end{array}$ \\
\hline Number of points treated & 1 point & $\begin{array}{l}\text { Multiple points } \\
\text { (10) }\end{array}$ & 1 point & Multiple points (2) & 1 point & $\begin{array}{l}\text { Multiple points } \\
\text { (3) }\end{array}$ \\
\hline Days of application & 21 & 7,14 and 21 & 10 & 2 & 21 & 14 \\
\hline $\begin{array}{l}\text { Total of energy emitted per } \\
\text { point (J)/Total of energy } \\
\text { per day }\end{array}$ & Not described & $\begin{array}{l}0.70 * / 0.10 \\
1.40 * / 0.10 \\
2.10 * / 0.10\end{array}$ & $39.90 * / 3.99 *$ & $48^{*} / 24^{* *}$ & $\begin{array}{l}24.36 * / 1.16 \\
97.44 * / 4.64 \\
194.88^{*} / 9.28\end{array}$ & $19.88^{*} / 1.42^{*}$ \\
\hline Treatment time per point (s) & Not described & 20 & 420 & 60 & $\begin{array}{l}38.66,154.66 \\
309.33\end{array}$ & 57 \\
\hline Beam area $\left(\mathrm{cm}^{2}\right)$ & $\begin{array}{l}0.02(\mathrm{HeNe}) \\
0.01 \text { (AsGa) }\end{array}$ & 0.10 & 1 & 0.04 & 0.116 & 0.14 \\
\hline Power density $\left(\mathrm{W} / \mathrm{cm}^{2}\right)$ & Not described & 0.5 & $0.0095^{*}$ & $1 *$ & $0.258^{*}$ & $0.178^{*}$ \\
\hline Energy density $\left(\mathrm{J} / \mathrm{cm}^{2}\right)$ & $\begin{array}{l}3(\mathrm{HeNe}) \\
0.03(\mathrm{AsGa})\end{array}$ & 10 & 4 & 60 & $10,40,80$ & 10 \\
\hline Power $(\mathrm{mW})$ & $\begin{array}{l}50(\mathrm{HeNe}) \\
45(\mathrm{AsGa})\end{array}$ & 5 & 9.5 & 40 & 30 & 25 \\
\hline Wavelength (nm) & $\begin{array}{l}632.8(\mathrm{HeNe}) \\
904(\mathrm{AsGa})\end{array}$ & 632.8 & 940 & 660 & 830 & 650 \\
\hline Light source & $\begin{array}{l}\text { Laser }(\mathrm{CW})- \\
\text { GaAlAs, Laser }(\mathrm{PW}) \\
-\mathrm{HeNe}\end{array}$ & Laser (CW) & LED & $\begin{array}{l}\text { Laser }(\mathrm{CW})- \\
\text { GaAlAs }\end{array}$ & $\begin{array}{l}\text { Laser }(\mathrm{CW})- \\
\text { GaAlAs }\end{array}$ & Laser (CW) \\
\hline
\end{tabular}

Abbreviations: LG (Group LLLT), LEDG (Group LED), Sham (control + crush), CG (Control group), NI (nerve injury), P (placebo), Dex (dexamethasone), GaAlAs (Gallium- Aluminized-Arsenide), LED (light-emitting diode), InGaAIP (Phosphate of Arsenic Indium Gallium).

*means that the original article does not show the parameter, but was calculated; **means that the article does not present the parameters consistently. 
Table 3. Experimental Design of the Studies - Part 3

\begin{tabular}{|c|c|c|c|c|c|c|}
\hline & $\begin{array}{l}\text { Wang et al, } \\
2_{2014^{8}}\end{array}$ & $\begin{array}{l}\text { Takhtfooladi et } \\
\text { al, } 2015^{14}\end{array}$ & $\begin{array}{l}\text { Andraus et al, } \\
2017^{12}\end{array}$ & $\begin{array}{l}\text { Ziago et al, } \\
2017^{5}\end{array}$ & $\begin{array}{l}\text { de Souza et al, } \\
2018^{19}\end{array}$ & $\begin{array}{l}\text { Mangueira et al, } \\
2018^{20}\end{array}$ \\
\hline Positive effect & YES & YES & YES & YES & YES & YES \\
\hline Sample & $\begin{array}{l}36 \text { Sprague } \\
\text { Dawley rats }\end{array}$ & 20 Wistar rats & 72 Wistar rats & 30 Wistar rats & 26 Swiss mice & 32 Wistar rats \\
\hline Division of groups & $\begin{array}{c}\text { CG, CG + LLLT } \\
\text { NI, LG }\left(3 \mathrm{~J} / \mathrm{cm}^{2}\right), \\
\text { LG }\left(8 \mathrm{~J} / \mathrm{cm}^{2}\right), \text { LG } \\
\left(15 \mathrm{~J} / \mathrm{cm}^{2}\right)\end{array}$ & CG, LG & $\begin{array}{l}\mathrm{CG}, \mathrm{NI}, \mathrm{LG}\left(35 \mathrm{~J} / \mathrm{cm}^{2}\right) \\
\mathrm{LG}\left(70 \mathrm{~J} / \mathrm{cm}^{2}\right), \mathrm{LG}(140 \\
\left.\mathrm{J} / \mathrm{cm}^{2}\right), \text { LG }\left(280 \mathrm{~J} / \mathrm{cm}^{2}\right)\end{array}$ & $\begin{array}{c}\text { CG, Sham, LG }(4 \\
\left.\mathrm{J} / \mathrm{cm}^{2}\right), \text { LG }(10 \mathrm{~J} / \\
\left.\mathrm{cm}^{2}\right), \text { LG }(50 \mathrm{~J} / \\
\left.\mathrm{cm}^{2}\right)\end{array}$ & $\begin{array}{c}\text { CG } \\
\text { Sham } \\
\text { LG }\left(10 \mathrm{~J} / \mathrm{cm}^{2}\right) \\
\text { LG + Dex } \\
\text { Dex }\end{array}$ & $\begin{array}{c}\text { CG } 1 \\
\text { CG2 } \\
\text { LG }(660 \mathrm{~nm}) \\
\text { LG }(808 \mathrm{~nm})\end{array}$ \\
\hline Number of points treated & 1 point & 1 point & Multiple points (3) & $\begin{array}{c}\text { Multiple points } \\
\text { (3) }\end{array}$ & 1 point & Multiple points (3) \\
\hline Days of application & 20 & 21 & 21 & 6 & 28 & 21 \\
\hline $\begin{array}{l}\text { Total of energy emitted (J)/ } \\
\text { Total of energy per day }\end{array}$ & $\begin{array}{c}228.40 * / 11.42 * \\
608.60 * / 30.43^{*} \\
1.141 .00 * / 57.05^{*}\end{array}$ & $3.15 * / 0.15^{*}$ & $\begin{array}{c}23.10 * / 1.10 \\
46.20 * / 2.20 \\
92.40 * / 4.40 \\
184.80 * / 8.80\end{array}$ & $\begin{array}{c}0.96 * / 0.16 \\
2.4 * / 0.4,12 * / 2\end{array}$ & $16.80 / 0.60$ & $84 * / 4$ \\
\hline Treatment time per point (s) & $67.2,179,35.6$ & 10 & $11,22,44,88$ & $4,10,50$ & 20 & 30 \\
\hline Beam area $\left(\mathrm{cm}^{2}\right)$ & 3.8 & 0.028 & 0.0324 & 0.04 & 0.06 & 0.03 \\
\hline Power density $\left(\mathrm{w} / \mathrm{cm}^{2}\right)$ & 0.044 & $0.535^{*}$ & 3.086 & 1 & $0.12^{*}$ & $3.33^{*}$ \\
\hline Energy density $\left(\mathrm{J} / \mathrm{cm}^{2}\right)$ & $3,8,15$ & 3 & $35,70,140,280$ & $4,10,50$ & 10 & 133 \\
\hline Power $(\mathrm{mW})$ & 170 & 15 & 100 & 40 & 30 & 100 \\
\hline Wavelength (nm) & 808 & 685 & 830 & 780 & 660 & 660,808 \\
\hline Light source & $\begin{array}{l}\text { Laser }(\mathrm{CW})- \\
\text { GaAlAs }\end{array}$ & $\begin{array}{l}\text { Laser }(\mathrm{CW})- \\
\text { InGaAIP }\end{array}$ & Laser $(C W)$ - GaAlAs & $\begin{array}{l}\text { Laser }(\mathrm{CW})- \\
\text { GaAlAs }\end{array}$ & $\begin{array}{l}\text { Laser }(\mathrm{CW})- \\
\text { GaAlAs }\end{array}$ & $\begin{array}{l}\text { Laser }(C W)-\text { InGaAIP } \\
\text { Laser }(C W)-\text { GaAlAs }\end{array}$ \\
\hline
\end{tabular}

Abbreviations: LG (Group LLLT), LEDG (Group LED), Sham (control + crush), CG (Control group), NI (nerve injury), P (placebo), Dex (dexamethasone), GaAlAs (Gallium- Aluminized-Arsenide), LED (light-emitting diode), InGaAIP (Phosphate of Arsenic Indium Gallium).

*means that the original article does not show the parameter, but was calculated; **means that the article does not present the parameters consistently.

energy density, potency, and time of application. The penetration of radiation depends on the length of the wave, and therefore the bigger the wavelength, the higher its penetration capacity. ${ }^{29}$

Andreo et $\mathrm{al}^{28}$ were to conduct a literature review on the effects of photobiomodulation with the use of LLLT on the treatment of peripheral nerve injury in experimental models. Studies with different types of animals (New Zealand rabbits, rats, and mice) were included, promoting a bias given anatomical differences and thus making it difficult to extrapolate such data. Thus, given such bias and information contained, it still presents a window for a discussion of protocols and parameters.

The standardization of the lesion through the load, time, and instrument used is of vital importance so that the studies can be reproduced in other animals. Based on the results of the review, seven articles used the machine model with deadweight; two used adjustable clamps, and ten used homeostatic models. In eight articles, they used the same load (5000 g) and the same compression time (10 minutes), what differentiated them were the instruments used. Still, times of 30 seconds were observed for homeostatic devices, predominantly seeds.

According to the Monte-Raso et al study, ${ }^{10}$ the tensile strength machine, deadweight machine, and adjustable tweezers are currently the most reliable instruments to standardize nerve crush injury. The authors compared the results obtained through the SFI from previous studies using the tensile strength machine and deadweight machine and compared these findings with a new instrument, the adjustable tweezers; the authors concluded through the SFI analysis that the results obtained with these instruments could cause the same type of nerve injury because they cause nerve fiber rupture without the rupture of most nerve supporting structures, which facilitates regeneration after injury. ${ }^{10}$

Effect of Photobiomodulation on Functionality In the study by Belchior et $\mathrm{al}^{1}(660 \mathrm{~nm}, 26.3 \mathrm{~mW}, 4 \mathrm{~J} /$ $\mathrm{cm}^{2}$ ), photobiomodulation showed significantly positive results about the functional recovery of the sciatic nerve after three weeks of treatment; however, in the study by Marcolino et al, ${ }^{24}$ the intervention $(830 \mathrm{~nm}, 30 \mathrm{~mW}, 4 \mathrm{~J} /$ $\mathrm{cm}^{2}$ ) was effective in accelerating gait recovery in the first 2 weeks. Barbosa et $\mathrm{al}^{2}\left(660 / 830 \mathrm{~nm}, 30 \mathrm{~mW}, 10 \mathrm{~J} / \mathrm{cm}^{2}\right)$ and Barbosa et al ${ }^{18}\left(660 \mathrm{~nm}, 30 \mathrm{~mW}, 10 \mathrm{~J} / \mathrm{cm}^{2}\right)$ only presented $P<0.05$ on the 14 th postoperative day compared to the control group. Marcolino et $\mathrm{al}^{22}$ showed that the treatment $\left(830 \mathrm{~nm}, 30 \mathrm{~mW}, 10 / 40 / 80 \mathrm{~J} / \mathrm{cm}^{2}\right.$ ) presented a difference on the 7 th day between the groups irradiated with $40 \mathrm{~J} / \mathrm{cm}^{2}$ and the simulated group $(P<0.05)$; on day 14 , the groups irradiated with $40 \mathrm{~J} / \mathrm{cm}^{2}$ and $80 \mathrm{~J} / \mathrm{cm}^{2}$ also presented better results when compared with simulations; however, on the 21st day, no difference was found between the groups $(P>0.05)$.

Besides, De Souza et $\mathrm{al}^{19}$ compared the outcome of effectiveness in the early functional recovery of the sciatic nerve of mice with demonstrations of the effects 
Table 4. Models of Sciatic Nerve Crush Injury

\begin{tabular}{|c|c|}
\hline Author & Injury Model \\
\hline Belchior et $\mathrm{al}^{1}$ & Homeostatic Forceps, compression during 30 seconds. \\
\hline Barbosa et $\mathrm{al}^{2}$ & Dead weight machine with a load of $5000 \mathrm{~g}$ during 10 minutes. \\
\hline Barbosa et al ${ }^{18}$ & Dead weight machine with a load of $5000 \mathrm{~g}$ during 10 minutes. \\
\hline Gigo-benatto et $\mathrm{al}^{7}$ & Homeostatic non-serrated tweezers, exerting a force of $54 \mathrm{~N}$ during 30 seconds. \\
\hline Gonçalves et $\mathrm{al}^{24}$ & Calibrated adjustable tweezers with a load of $5000 \mathrm{~g} / \mathrm{cm}^{2}$ during 10 minutes. \\
\hline Marcolino et $\mathrm{al}^{21}$ & Dead weight machine with a load of $5000 \mathrm{~g}$ during 10 minutes. \\
\hline Câmara et $\mathrm{al}^{3}$ & Homeostatic Tweezers, compressed during 30 seconds. \\
\hline Tomazini et al ${ }^{25}$ & Homeostatic Tweezers, compressed during 30 seconds. \\
\hline Gomes et $\mathrm{al}^{26}$ & Homeostatic Tweezers, compressed during 30 seconds. \\
\hline Serafim et $\mathrm{al}^{23}$ & Homeostatic Tweezers, with $20 \mathrm{~g}$ of force during 30 seconds. \\
\hline Alcântara et $\mathrm{al}^{27}$ & Homeostatic non-serrated tweezers, exerting a force of $54 \mathrm{~N}$ during 30 seconds. \\
\hline Marcolino et $\mathrm{al}^{22}$ & Dead weight machine with a load of $5000 \mathrm{~g}$ during 10 minutes. \\
\hline Akgul et al ${ }^{13}$ & Dead weight machine with a load of $5.000 \mathrm{~g}$ equal to $50 \mathrm{~N}$ during 10 minutes. \\
\hline Wang et $\mathrm{al}^{8}$ & Homeostatic non-serrated tweezers exerting a force of $54 \mathrm{~N}$ during 30 seconds. \\
\hline Takhtfooladi et al ${ }^{14}$ & Homeostatic tweezers exerting a force of $54 \mathrm{~N}$ during 30 seconds. \\
\hline Andraus et $\mathrm{al}^{12}$ & Calibrated adjustable tweezers with $5000 \mathrm{~g}$ during 10 minutes. \\
\hline Ziago et al ${ }^{5}$ & Dead weight machine with a load of $15000 \mathrm{~g}$ during 10 minutes. \\
\hline de Souza et al ${ }^{19}$ & Dead weight machine with a load of 5000 g during 10 minutes. \\
\hline Mangueira et $\mathrm{al}^{20}$ & Straight clamp exerting a force of $6 \mathrm{~N}$ during 30 seconds. \\
\hline
\end{tabular}

of photobiomodulation when compared or associated with dexamethasone (Dex), an anti-inflammatory glucocorticoid, on the enhancement of motor function in PNS lesions. Thus, after 28 days of intervention, it was observed that only the group treated with photobiomodulation obtained better results when compared to the other groups for the SFI. For SSI, the group treated with photobiomodulation/Dex obtained better results in the intergroup comparison.

Takhtfooladi et $\mathrm{al}^{14}$ used a functional analysis of the gait and static footprint (SSI) to evaluate the functionality of rats. The results were significant between two groups on the 14 th and 21 st postoperative days $(P<0.05)$ and in the intragroup at different periods, concluding that photobiomodulation (685 nm, $15 \mathrm{~mW}, 3 \mathrm{~J} / \mathrm{cm}^{2}$ ) accelerated the improvement of sciatic nerve function after crush injury.

The most used outcome variable was SFI. Generally, experimental studies on peripheral nerve regeneration are analyzed through histology, morphology, morphometry, electrophysiology, biochemistry, and immunology. ${ }^{3,5,17,19,20,22,30}$ All studies lasted for 21 days, and the analyses were performed on the $7 \mathrm{th}, 14 \mathrm{th}$, and $21 \mathrm{st}$ days after the nerve injury. However, de Souza et al ${ }^{19}$ still discusses the lack of standardization of the parameters used in other studies, as well as the low volume of research regarding the associated effects with other tools on peripheral nerve injury.
Effect of Photobiomodulation on the Aspects of Morphological, Histological and Inflammatory Processes In the study by Gonçalves et $\mathrm{al}^{24}$ the presence of inflammatory infiltrates, and fibroblasts, destruction of the myelin sheath, and axonal degeneration were analyzed. The results of their study revealed a statistically significant difference in three parameters: The L14 group had a higher amount of fibroblasts $(P=0.0001)$, lower myelin sheath degeneration $(P=0.007)$, and a smaller amount of inflammatory infiltrate $(P=0.001)$. The application of the low power $\left(830 \mathrm{~nm}, 30 \mathrm{~mW}, 4 \mathrm{~J} / \mathrm{cm}^{2}\right)$ contributed to the reduction in the inflammatory process. Câmara et $\mathrm{al}^{3}\left(904 \mathrm{~nm}, 26.3 \mathrm{~mW}, 4 \mathrm{~J} / \mathrm{cm}^{2}\right)$ analyzed the proliferation of Schwann cells and neurons, number, and diameter of axons. They observed a significant difference between the groups throughout 14 and 21 days besides the increase in the total number of axons and better quality of the regeneration process due to the increase of large-caliber axons after 21 days of treatment.

Tomazini et $\mathrm{a}^{25}$ analyzed the number of nerve fibers of sensory neurons present in the L5 spinal ganglion. They concluded that through the quantitative analysis of the axons, the treatment $(632.8 / 904 \mathrm{~nm}, 45 / 50 \mathrm{~mW}$, $3 \mathrm{~J} / \mathrm{cm}^{2}$, and $30 \mathrm{~mJ}$ ) did not stimulate peripheral nerve regeneration.

Gomes et $\mathrm{al}^{20}$ analyzed the mRNA expression of neurotrophic factors (brain-derived neurotrophic factor/ BDNF, nerve growth factor/NGF, neurotrophin 3/NT-3) and the inflammatory marker nitric oxide (iNOS). After 


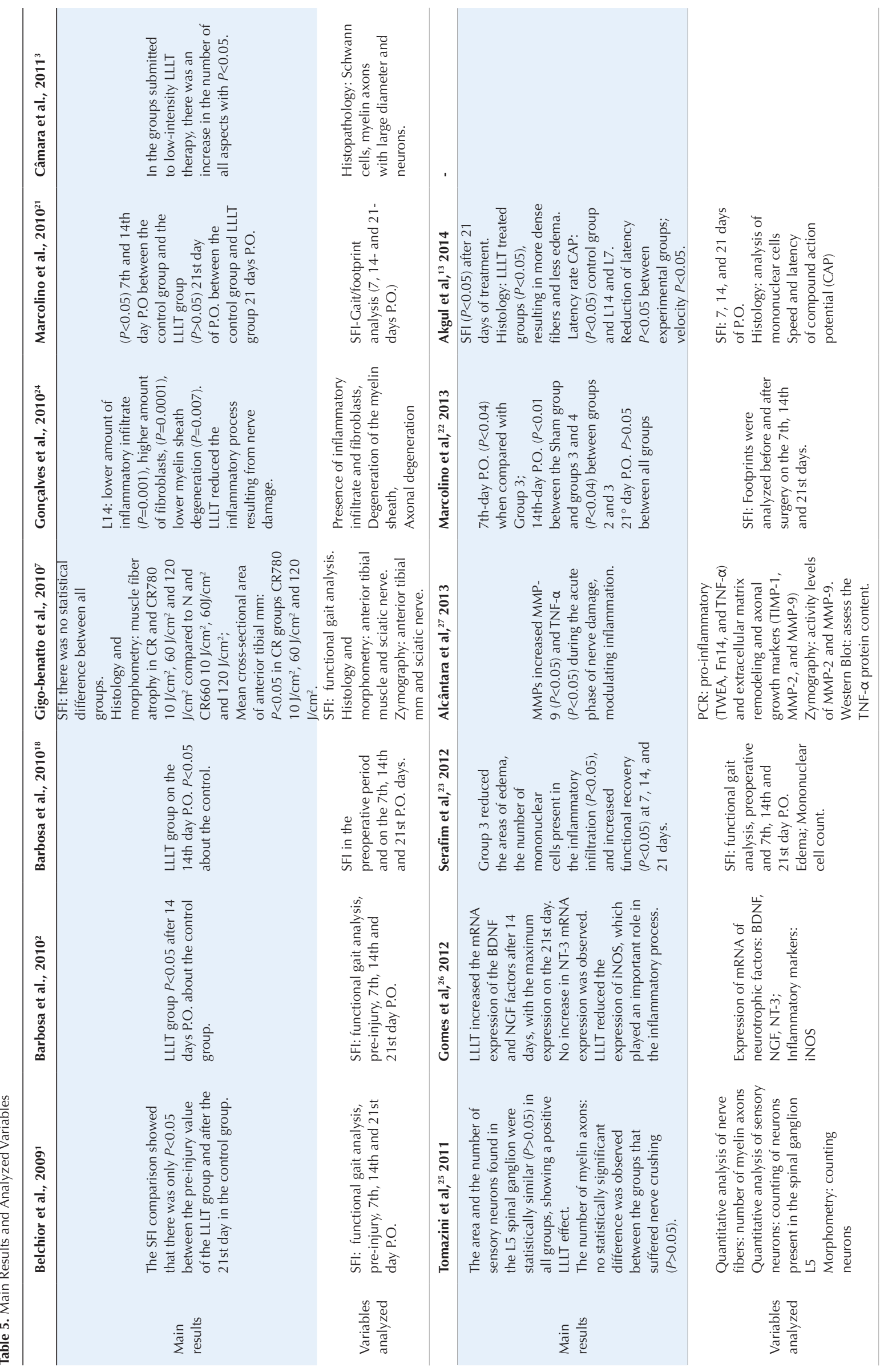



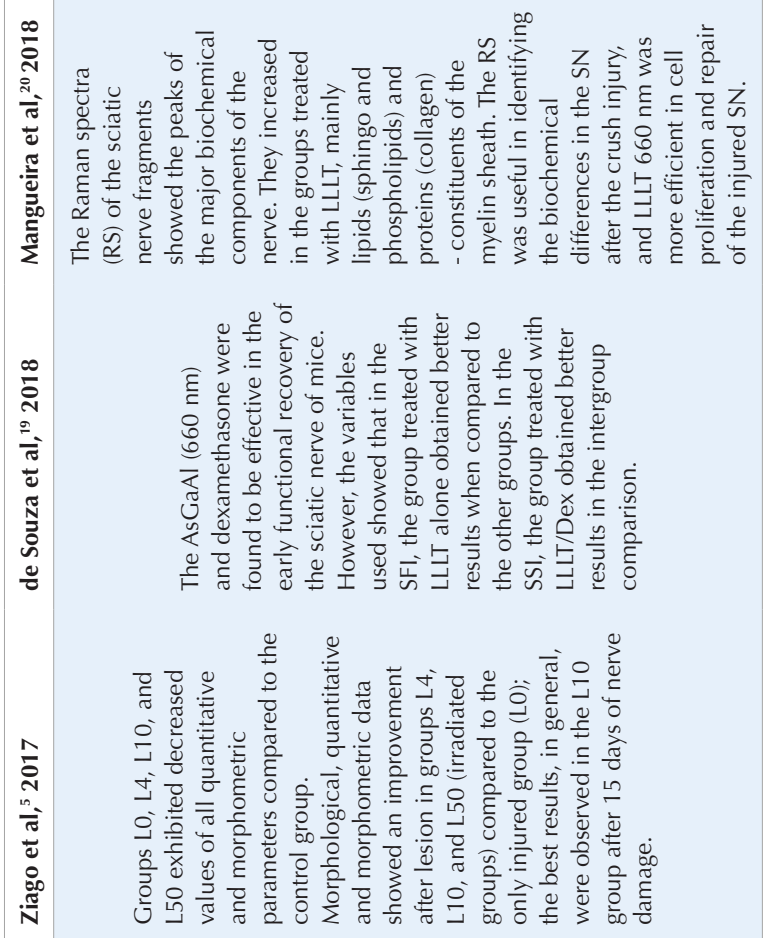

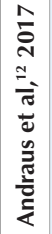

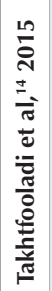

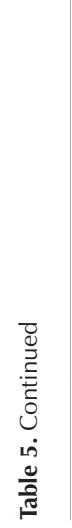

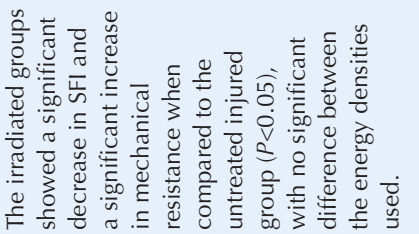
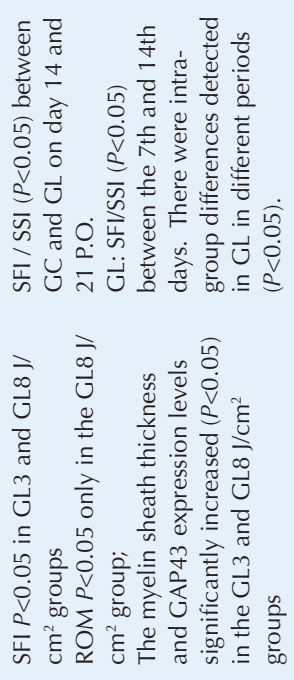

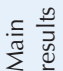
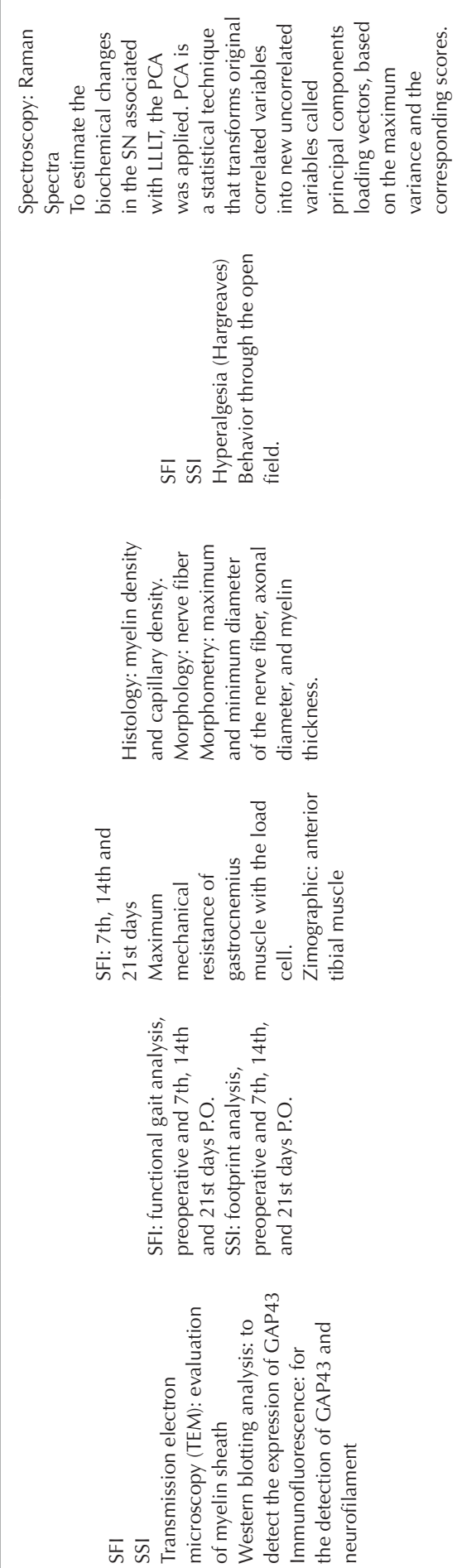

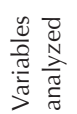

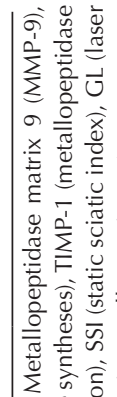

这寒

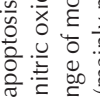

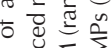

它 $\sum_{0} \sum$

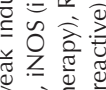

产竞离

웅

일

员 홍

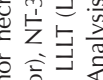

要守

关专专

了.

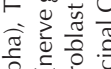

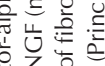

尊示㝴

定证

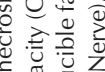

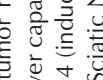

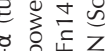

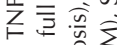

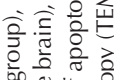

on

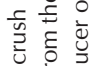

능 웡.

x)

항

ब。

次

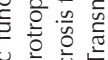

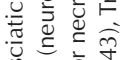

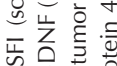

过宗

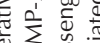

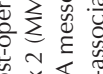

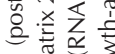

O

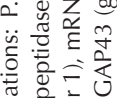




\section{Total of energy}

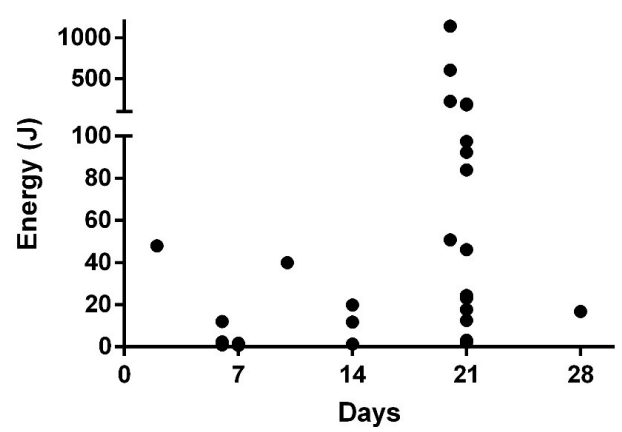

Figure 2. Total Energy applied in Related Studies With Photobiomodulation and Peripheral Nerve Injury Included in This Review.

the nerve injury, and iNOS increase occurs, resulting in the recruitment of inflammatory cells to the lesion site, increasing the production and release of pro-inflammatory mediators, reducing the nerve recovery process. However, BDNF and NGF play an essential role in the promotion of neuronal survival and axonal regeneration. In the study after irradiation $\left(632.8 \mathrm{~nm}, 5 \mathrm{~mW}, 10 \mathrm{~J} / \mathrm{cm}^{2}\right)$, the rapid response and progressive increase of BDNF and NGF expression were observed in the first two weeks after the nerve injury, followed by a continuous rise up to the 21 st day and reduction of iNOS expression. The authors concluded that photobiomodulation treatment played an important role in reducing the inflammatory process, contributing to peripheral nerve regeneration.

Alcântara et $\mathrm{al}^{27}$ analyzed the gene expression of TWEAK, Fn14, and TNF-a, extracellular matrix remodeling, axonal growth markers (TIMP-1, MMP-2, and MMP-9) and MMP-2 and MMP-9 activity levels. MMP-9 is secreted by macrophages and Schwann cells, and its activity is related to the intensity of myelin degradation in the distal nerve segment after injury. In this study, the intervention $(660 \mathrm{~nm}, 40 \mathrm{~mW}, 40$, and 60 $\mathrm{J} / \mathrm{cm}^{2}$ ) provided increased MMP activity, mainly MMP-9 $(P<0.05)$ and TNF- $\alpha(P<0.05)$ during the acute phase of nerve damage, modulating inflammation. Still, there was no difference in the gene expression of TNF-a, TWEAK, and Fn14 among all experimental groups. Thus, the authors concluded that the characterization of the action mechanisms of photobiomodulation and adequate parameters in the nervous remodeling after the injury is important for the effectiveness of the treatment.

Ziago et $\mathrm{al}^{5}$ analyzed the maximum and minimum diameter of nerve fibers, axon diameter, and myelin sheath thickness. Morphological, quantitative, and morphometric data revealed improvement after injury in the $\mathrm{L} 4 \mathrm{~J} / \mathrm{cm}^{2}, \mathrm{~L} 10 \mathrm{~J} / \mathrm{cm}^{2}$ and $\mathrm{L} 50 \mathrm{~J} / \mathrm{cm}^{2}$ groups treated with photobiomodulation $\left(780 \mathrm{~nm}, 40 \mathrm{~mW}, 4 / 10 / 50 \mathrm{~J} / \mathrm{cm}^{2}\right)$ compared to the only injured group (L0); the best results were generally observed in the $\mathrm{L} 10 \mathrm{~J} / \mathrm{cm}^{2}$ group after 15 days of nerve damage.
Finally, the leading research by Mangueira et $\mathrm{al}^{20}$ aimed to identify biochemical changes in sciatic nerve after crush injury and photobiomodulation with $660 \mathrm{~nm}$ and $808 \mathrm{~nm}$ by Raman spectroscopy (RS) analysis. The RS has been used as a tool for the identification of molecular biomarkers in tissues and fluids aimed at characterization and evaluation of the physiological status in biological processes and diagnoses. The multivariate analysis by principal component analysis revealed specific differences between the groups, where the nerve fragments showed the peaks of the major biochemical components of the nerve, especially sphingolipids, phospholipids, glycoproteins, and collagen. The features identified in some of the principal components on biochemical elements present on the sciatic nerve and increased in the groups treated with photobiomodulation. Therefore, the RS was useful in identifying the biochemical differences in the sciatic nerve after the crush injury, and LLLT $660 \mathrm{~nm}$ was more efficient than the $808 \mathrm{~nm}$ in cell proliferation and repair of the injured sciatic nerve, indicating replacement with increased Schwann cells and reconstitution of the myelin sheath after 21 days of LLLT.

Effect of Photobiomodulation on the Morphological and Histological Aspects of Muscle Tissue

The study of Gigo-benatto et $\mathrm{al}^{7}$ analyzed the SFI, histology, morphometry, and zymography of the sciatic nerve and anterior tibial muscle after photobiomodulation therapy (660 and $780 \mathrm{~nm}, 40 \mathrm{~mW}, 10 / 60 / 120 \mathrm{~J} / \mathrm{cm}^{2}$ ). The results showed that the $660 \mathrm{~nm}$ photostimulation using 10 or 60 $\mathrm{J} / \mathrm{cm}^{2}$ recovered muscle fibers, myelin, and nerve fibers compared to the control group and additionally increased the MMP-2 activity in the nerve and decreased both activities of MMP-2 in muscle and MMP-9 in the nerve. MMP-2 and MMP-9 are axonal growth markers in nerve tissue. MMP-2 in the nerve fiber can reorganize the basal lamina by degrading the type IV collagen and allowing the cone of axonal growth to advance. Based on the results of the study, the authors concluded that increased MMP2 and low MMP-9 values aided in the process of nerve regeneration, and the reduction of MMP-2 might have generated beneficial effects on muscle tissue, possibly causing less damage to muscle fibers. ${ }^{7}$

The photostimulation with $780 \mathrm{~nm}$ using $10 \mathrm{~J} / \mathrm{cm}^{2}$ decreased MMP-9 activity in the nerve compared to the crushing and control groups, also restoring normal myelin levels and the cross-sectional area of nerve fibers. The two wavelengths with an energy density of 60 and $120 \mathrm{~J} / \mathrm{cm}^{2}$ decreased MMP-2 activity in muscle compared to both groups. The photobiomodulation therapy with $780 \mathrm{~nm}$ did not prevent the atrophy of muscle fibers and the recuperation of function in the irradiated groups, which did not differ from CR that was not treated. Based on these results, the authors concluded that the $660 \mathrm{~nm}$ using 10 or $60 \mathrm{~J} / \mathrm{cm}^{2}$ is capable of accelerating neuromuscular recovery after nerve injury in rats ${ }^{7}$. 
Serafim et $\mathrm{al}^{23}$ used LED (940 nm, $9.5 \mathrm{~mW}, 4 \mathrm{~J} / \mathrm{cm}^{2}$ ) and analyzed SFI, edema, and mononuclear cell counts. After photobiomodulation therapy, the morphological analysis of the nerve indicated that intervention could reduce the migration of mononuclear cells to damaged tissue, which reduces the areas of edema and degeneration of nerve fibers and increases functional recovery scores in 7, 14 and 21 days, with statistical significance for all variables; the results suggest that the use of photobiomodulation at $940 \mathrm{~nm}$ improves morphofunctional recovery and nerve regeneration.

Akgul et $\mathrm{al}^{13}$ used the photobiomodulation $(650 \mathrm{~nm} / 25$ $\mathrm{mW}, 10 \mathrm{~J} / \mathrm{cm}^{2}$ ) and analyzed the SFI, nuclear cell count, speed, and latency of the compound action potential (CAP) of the sciatic nerve. The SFI results showed that there was a significant difference after 21 days of treatment; CAP latency significantly decreased $(P<0.05)$ in the delayed group. A histological examination confirmed that the number of mononuclear cells was lower $(P<0.05)$ in the early and late groups. Thus, the results supported the hypothesis that photobiomodulation could accelerate the rate of recovery in injured peripheral nerves in this animal model. Although both groups had positive results, the delayed group presented better recovery.

Wang et $\mathrm{al}^{8}$ performed a functional analysis through SFI and ROM, myelin sheath microscopy, expression of the growth associated with protein 43 (GAP43), and neurofilament. After photobiomodulation therapy (808 $\mathrm{nm}, 170 \mathrm{~mW}, 3 / 8 / 15 \mathrm{~J} / \mathrm{cm}^{2}$ ), myelin sheath thickness and expression levels of GAP43 increased significantly in GL3 and GL8 $\mathrm{J} / \mathrm{cm}^{2}$ groups. The SFI obtained positive results $(P<0.05)$ in the GL3 and GL8 $\mathrm{J} / \mathrm{cm}^{2}$ groups, and ROM only presented statistically positive results in the GL8 J/ $\mathrm{cm}^{2}$ group. In conclusion, the application immediately after the injury brought beneficial effects on the regeneration of the sciatic nerve.

Andraus et $\mathrm{al}^{12}$ evaluated the SFI, the maximum mechanical resistance of the gastrocnemius muscle with a load cell, and the zymography of the anterior tibial muscle. The groups irradiated $(830 \mathrm{~nm}, 100 \mathrm{~mW}$, $35 / 70 / 140 \mathrm{~J} / \mathrm{cm}^{2}$ ) showed a significant decrease in the SFI and a considerable increase in mechanical resistance when compared to the untreated injured group $(P<0.05)$, with no significant difference between the energy densities used. However, there was no statistically significant difference between the groups for the activity of MMP2 in the proactive band; in the intermediate band, the activity was significantly higher $(P<0.05)$ for the groups irradiated with 35,70 , and $140 \mathrm{~J} / \mathrm{cm}^{2}$, and in the active band, the activity was significantly more intense in the group irradiated with $280 \mathrm{~J} / \mathrm{cm}^{2}$. The study demonstrates that sciatic nerve damage, with consequent muscle denervation, benefits by photobiomodulation therapy, which restores active neuromuscular function, and MMP2 activates and increases maximum burst strength.

All the articles selected for the review present varied parameters; the wavelength used ranges from 632.8 to 940 $\mathrm{nm}$, power from 5 to $170 \mathrm{~mW}$, and energy density from $30 \mathrm{~mJ}$ to $280 \mathrm{~J} / \mathrm{cm}^{2}$. Regarding the parameter description used in the studies, only the values of wavelength, power, and energy density were presented in all articles; the total energy emitted $(J)$ and power density $\left(\mathrm{W} / \mathrm{cm}^{2}\right)$ were the parameters less described by the authors. Only the study by Ziago et $\mathrm{al}^{5}$ contained all the parameters selected in our review. Of the 19 studies included only one study ${ }^{23}$ used LED as a form of treatment, revealing the evidence that the most studied therapeutic model is the LLLT.

The vast majority of studies with photobiomodulation demonstrated positive results if applied for at least 10 seconds in a single point. This indicates that the positive effects can be achieved by a short period of application. Regarding energy density, the studies analyzed showed that low, intermediate, and high doses could react similarly in peripheral nerve regeneration.

Almost all studies that lasted 21 days $^{1-3,13,14,18,20-23,25,26}$ presented better results in comparison to the other studies, only in the study of Tomazini et $\mathrm{al}^{25}$ was there no significant improvement. Negative results may be associated with the values of power, energy density, and the irradiation site because the wavelength $632.8 \mathrm{~nm}$ was used in the study by Gomes et $\mathrm{al}^{26}$ and $904 \mathrm{~nm}$ was used in the study by Câmara et $a{ }^{3}{ }^{3}$ with different values of power, energy density, and the site of application. In these studies, the results were significant. Besides, it should be noted that for the application of $632.8 \mathrm{~nm}$, the use was performed with a distance of two centimeters from the surface of the skin and, therefore, not be the best technique for application given the loss of present energy.

Most of the studies that analyzed the functionality, morphology, histology, inflammatory process, ROM, and maximal muscle strength showed statistically significant results; only the study of Gigo-Benatto et $\mathrm{al}^{7}$ did not show significant improvement among all the groups analyzed in SFI. However, it discusses the property of the information contained in that study regarding the parameters used, given that the energy information is not appropriate when evaluated. For example, given the energy formula being Power (W) x Time (s), we can use 0.04 (W) x 60 (s) if the information of a group is $40 \mathrm{~mW}$ and 60 seconds of exposure. Thus, the value reached would be $2.4 \mathrm{~J}$, different from the $24 \mathrm{~J}$ exposed in the manuscript, among other values detected. Another problem is to understand the time used, where they use the legend of 0.3 minutes, making interpretation difficult. If it were carried by energy obtained and demonstrated in the figure, it would represent 10 seconds. Therefore, the lack of positive effects may also be related to incorrect parameters during the protocol performed.

\section{Clinical Perspectives}

Oliveira et al ${ }^{30}$ reviewed the benefits of photobiomodulation in nerve repair in experimental studies (in vivo and in 
vitro) and clinical studies (clinical trials and case studies) during the period from 1987 to 2012. Thirty-two studies were included in the review; among them, only seven studies were in humans and 1 study in sural nerve cells. In studies with humans, the most affected nerves were: inferior alveolar, mental and lingual, and in one of the studies, paresthesia in the lower lip, chin, and gums was evaluated. The irradiation parameters described were: wavelength (660 to $830 \mathrm{~nm})$, power $\left(550 \mathrm{~mW} / \mathrm{cm}^{2}\right.$ to 50 $\mathrm{mW}$ ), dose (1 to $\left.140 \mathrm{~J} / \mathrm{cm}^{2}\right)$, and treatment time per point (8 to 90 seconds). All studies in humans showed a positive effect of photobiomodulation on nerve recovery.

Oliveira et $\mathrm{al}^{31}$ carried out a prospective study of 125 clinical cases with the objective of evaluating the efficacy of photobiomodulation in the acceleration and recovery of sensitivity after orthognathic surgeries during the period from 2007 to 2013. The authors concluded that sensitivity recovery correlates with the patient's age $(P=0.015)$, the interval between surgery, and the start of treatment $(P=0.002)$.

Peripheral nerve injury research in experimental models exists to enable understanding of the cellular and molecular mechanisms that limit functional regeneration, restricting and reducing the bias found in clinical research with humans that can be experimentally manipulated in a viable manner. The peripheral nerves of rodents are morphologically comparable to those of humans. ${ }^{11}$

Translating the available evidence from animal studies to clinical studies in humans ends up generating a large window, in which, in the current literature search, to our knowledge, there is only one study of clinical applicability. Rochkind et $\mathrm{al}^{32}$ selected eighteen patients with clinical signs and symptoms of peripheral nerve or brachial plexus injury, where the parameters used were a continuous wavelength of $780 \mathrm{~nm}, 250 \mathrm{~mW}$ power, with a $6 \mathrm{~mm}^{2}$ laser diode. There were two groups, intervention and placebo. It was performed during 21 consecutive days for the spinal cord, and each level was irradiated for $60 \mathrm{~min} / \mathrm{d}$ $\left(150 \mathrm{~J} / \mathrm{mm}^{2}\right)$, totaling $120 \mathrm{~min} / \mathrm{d}\left(300 \mathrm{~J} / \mathrm{mm}^{2}\right)$. Already for the peripheral nerve area, each section was irradiated for $60 \mathrm{~min} / \mathrm{d}\left(150 \mathrm{~J} / \mathrm{mm}^{2}\right)$, totaling $180 \mathrm{~min} / \mathrm{d}(450 \mathrm{~J} /$ $\mathrm{mm}^{2}$ ). The results in the photobiomodulation group showed a statistically significant improvement in motor function in the previously partially paralyzed limbs, compared to the placebo group. The electrophysiological analysis also showed a statistically significant increase in the recruitment of voluntary muscle activity in the photostimulation group. Thus, the study suggests that in patients with long-term peripheral nerve injury, 780-nm photobiomodulation therapy can progressively improve nerve function, leading to a significant functional recovery.

Despite the increasing knowledge of cellular and molecular mechanisms involved in peripheral nerve regeneration, the clinical outcome of nerve repair in humans remains challenging because functional recovery depends on multiple factors that are clinically relevant, such as the severity, type, and level of injury, the type of injured nerve fiber, and the patient's age. At the same time, multiple mechanisms contribute to the success or failure of the motor recovery after the nerve injury. These characteristics show that the lack of standardization of the sample hinders the research in humans regarding peripheral nerve regeneration. For the development of new treatment strategies, it is necessary to identify the primary factors that may impair rehabilitation. ${ }^{11}$ Thus, because of the important number of animal studies and the low number in humans, clinical trials are necessary to translate the results of experimental studies.

\section{Conclusion}

Based on the results, it can be concluded that the therapeutic window of photobiomodulation, with wavelength (632.8 to $940 \mathrm{~nm}$ ), power (5 to $170 \mathrm{~mW}$ ), energy density ( 3 to $280 \mathrm{~J} / \mathrm{cm}^{2}$ ), and energy $(0.70 \mathrm{~J}$ to $1.141 \mathrm{~J})$, has positive effects on the process of nerve regeneration, peripheral and neuromuscular repair, through the expression of cytokines and growth factors aiding in the modulation of the inflammatory process, improvement of the morphological aspects and restoration of the functionality of the animals in a short period. The studies also demonstrate that the nerve crush injury model is the most used to study the properties of photobiomodulation, highlighting photobiomodulation therapy as the most used therapeutic modality among the studies.

\section{Ethical Considerations}

Not applicable.

\section{Conflict of Interests}

The authors declare no conflict of interest.

\section{References}

1. Belchior AC, dos Reis FA, Nicolau RA, Silva IS, Perreira $\mathrm{DM}$, de Carvalho Pde T. Influence of laser $(660 \mathrm{~nm})$ on functional recovery of the sciatic nerve in rats following crushing lesion. Lasers Med Sci. 2009;24(6):893-9. doi: 10.1007/s10103-008-0642-3.

2. Barbosa RI, Marcolino AM, de Jesus Guirro RR, Mazzer N, Barbieri CH, de Cássia Registro Fonseca M. Comparative effects of wavelengths of low-power laser in regeneration of sciatic nerve in rats following crushing lesion. Lasers Med Sci. 2010;25(3):423-430. doi: 10.1007/ s10103-009-0750-8.

3. Câmara CN, Brito MV, Silveira EL, Silva DS, Simões VR, Pontes RW. Histological analysis of low-intensity laser therapy effects in peripheral nerve regeneration in Wistar rats. Acta Cir Bras. 2011;26(1):12-8. doi: 10.1590/ S0102-86502011000100004.

4. Oliveira FB, Pereira VM, da Trindade AP, Shimano AC, Gabriel RE, Borges AP. Action of therapeutic laser and ultrasound in peripheral nerve regeneration. Acta 
Ortop Bras. 2012;20(2):98-103. doi: 10.1590/S141378522012000200008.

5. Ziago EK, Fazan VP, Iyomasa MM, Sousa LG, Yamauchi PY, da Silva EA, et al. Analysis of the variation in lowlevel laser energy density on the crushed sciatic nerves of rats: a morphological, quantitative, and morphometric study. Lasers Med Sci. 2017;32(2):369-378. doi: 10.1007/ s10103-016-2126-1.

6. Grinsell D, Keating CP. Peripheral nerve reconstruction after injury: A review of clinical and experimental therapies. Biomed Res Int. 2014;2014:698256. doi: 10.1155/2014/698256.

7. Gigo-Benato D, Russo TL, Tanaka EH, Assis L, Salvini TF, Parizotto NA. Effects of 660 and $780 \mathrm{~nm}$ low-level laser therapy on neuromuscular recovery after crush injury in rat sciatic nerve. Lasers Surg Med. 2010;42(9):673-82. doi: 10.1002/lsm.20978.

8. Wang CZ, Chen YJ, Wang YH, Yeh ML, Huang MH, Ho ML, et al. Low-level laser irradiation improves functional recovery and nerve regeneration in sciatic nerve crush rat injury model. PLoS One. 2014;9(8):e103348. doi: 10.1371/journal.pone.0103348.

9. Dias FJ, Issa JP, Iyomasa MM, Coutinho-Netto J, Calzzani R, Iyomasa DM, et al. Application of a low-level laser therapy and the purified protein from natural latex (Hevea brasiliensis) in the controlled crush injury of the sciatic nerve of rats: A morphological, quantitative, and ultrastructural study. BioMed Res Int. 2013;2013:597863. doi: 10.1155/2013/597863.

10. Monte-Raso VV, Moro CA, Mazzer N, Fonseca M, Fazan V, Barbieri G, et al. A new adjustable clamp for the production of injuries by crushing the rat's sciatic nerve. Acta Ortop Bras. 2009;17(4):236-238. doi: 10.1590/S1413-78522009000400009. [In Portuguese]

11. Irintchev A. Potentials and limitations of peripheral nerve injury models in rodents with particular reference to the femoral nerve. Ann Anat. 2011;193(4):276-85. doi: 10.1016/j.aanat.2011.02.019.

12. Andraus RAC, Maia LP, de Souza Lino AD, Fernandes KBP, de Matos Gomes MV, de Jesus Guirro RR, et al. LLLT actives MMP-2 and increases muscle mechanical resistance after nerve sciatic rat regeneration. Lasers Med Sci. 2017;32(4):771-778. doi: 10.1007/s10103-0172169-y.

13. Akgul T, Gulsoy M, Gulcur HO. Effects of early and delayed laser application on nerve regeneration. Lasers Med Sci. 2014;29(1): 351-7. doi: 10.1007/s10103-0131355-9.

14. Takhtfooladi MA, Jahanbakhsh F, Takhtfooladi HA, Yousefi K, Allahverdi A. Effect of low-level laser therapy $\left(685 \mathrm{~nm}, 3 \mathrm{~J} / \mathrm{cm}^{2}\right)$ on functional recovery of the sciatic nerve in rats following crushing lesion. Lasers Med Sci. 2015;30(3):1047-52. doi: 10.1007/s10103-015-1709-6.

15. Yazdani SO, Golestaneh AF, Shafiee A, Hafizi M, Omrani HA, Soleimani M. Effects of low level laser therapy on proliferation and neurotrophic factor gene expression of human schwann cells in vitro. J Photochem Photobiol B. 2012;107:9-13. doi: 10.1016/j.jphotobiol.2011.11.001.

16. Morries LD, Cassano P, Henderson TA. Treatments for traumatic brain injury with emphasis on transcranial near-infrared laser phototherapy. Neuropsychiatr Dis Treat. 2015;11:2159-75. doi: 10.2147/NDT.S65809.

17. Galvão T, Pansani T, Harrad D. Principais itens para relatar Revisões sistemáticas e Meta-análises: A recomendação PRISMA. Epidemiol Serv Saúde. 2015;24(2):335-342. [In portuguese]

18. Barbosa RI, Marcolino AM, Guirro RR, Mazzer N, Barbieri $\mathrm{CH}$, Fonseca M. Effect of low- power laser $(660 \mathrm{~nm})$ on regeneration of injured rat sciatic nerve. Fisioterapia e Pesquisa. 2010;17(4):294-299. doi: 10.1590/ S1809-29502010000400002. [In portuguese]

19. de Souza LG, Marcolino AM, Kuriki HU, Gonçalves ECD, Fonseca MCR, Barbosa RI. Comparative effect of photobiomodulation associated with dexamethasone after sciatic nerve injury model. Lasers Med Sci. 2018;33(6):1341-9. doi: 10.1007/s10103-018-2494-9.

20. de Almeida Melo Maciel Mangueira M, Maciel Mangueira N, Pereira Gama Filho O, Moysés de Oliveira M, Albuquerque Heluy R, Silveira L Jr, et al. Biochemical changes in injured sciatic nerve of rats after low-level laser therapy ( $660 \mathrm{~nm}$ and $808 \mathrm{~nm}$ ) evaluated by Raman spectroscopy. Lasers Med Sci. 2019;34(3):525-35. doi: 10.1007/s10103-018-2627-1.

21. Marcolino AM, Barbosa RI, Neves LM, Vinas TS, Duarte DT, Mazzer N, et al. Laser de baixa intensidade $(830 \mathrm{~nm})$ na recuperação funcional do nervo isquiático de ratos. Acta Ortop Brasil. 2010;18(4):207-211. doi: 10.1590/ S1413-78522010000400007.

22. Marcolino AM, Barbosa RI, das Neves LM, Mazzer $\mathrm{N}$, de Jesus Guirro RR, de Cássia Registro Fonseca M. Assessment of functional recovery of sciatic nerve in rats submitted to low-level laser therapy with different fluences. An experimental study. I Hand Microsurg. 2013;5(2):49-53. doi: 10.1007/s12593-013-0096-0.

23. Serafim KG, Ramos Sde P, de Lima FM, Carandina M, Ferrari O, Dias IF, et al. Effects of $940 \mathrm{~nm}$ light-emitting diode (led) on sciatic nerve regeneration in rats. Lasers Med Sci. 2011;27(1):113-119. doi: 10.1007/s10103-0110923-0.

24. Gonçalves RB, Marques JC, Monte-Raso VV, Zamarioli A, Carvalho LC, Fazan VP, et al. Efeitos da aplicação do laser de baixa potência na regeneração do nervo isquiático de ratos. Fisioterapia e Pesquisa. 2010;17(1): 34-39. doi: 10.1590/S1809-29502010000100007. [In Portuguese].

25. Tomazini AP, Souza LG, Araújo EJ, Azevedo JF, Araújo $\mathrm{CV}$, Araújo SI, et al. Efeito do laser terapêutico de baixa potência no gânglio da raiz dorsal L5 de camundongos submetidos ao esmagamento do nervo ciático. Braz J Vet Res Anim Sci. 2011;48(1): 54-61. doi: 10.11606/S141395962011000100007. [In Portuguese].

26. Gomes LE, Dalmarco EM, André ES. The brain-derived neurotrophic factor, nerve growth factor, neurotrophin-3, and induced nitric oxide synthase expressions after low-level laser therapy in an axonotmesis experimental model. Photomed Laser Surg. 2012;30(11):642-47. doi: 10.1089/pho.2012.3242.

27. Alcântara CC, Gigo-Benato D, Salvini TF, Oliveira AL, Anders JJ, Russo TL. Effect of low-level laser therapy (LLLT) on acute neural recovery and inflammation- 
related gene expression after crush injury in rat sciatic nerve. Lasers Surg Med. 2013;45(4): 246-52. doi: $10.1002 / 1 \mathrm{sm} .22129$.

28. Andreo L, Soldera CB, Ribeiro BG, de Matos PRV, Bussadori SK, Fernandes KPS, et al. Effects of photobiomodulation on experimental models of peripheral nerve injury. Lasers Med Sci. 2017;32(9):215565. doi: 10.1007/s10103-017-2359-7.

29. Enwemeka CS. Intricacies of dose in laser phototherapy for tissue repair and pain relief. Photomed Laser Surg. 2009;27(3):387-393. doi: 10.1089/pho.2009.2503.

30. de Oliveira RF, da Silva AC, Simões A, Youssef MN, de Freitas PM. Laser Therapy in the Treatment of
Paresthesia: A Retrospective Study of 125 Clinical Cases. Photomed Laser Surg. 2015;33(8):415-23. doi: 10.1089/ pho.2015.3888.

31. de Oliveira RF, de Andrade Salgado DM, Trevelin LT, Lopes RM, da Cunha SR, Aranha AC, et al. Benefits of laser phototherapy on nerve repair. Lasers Med Sci. 2014;30(4):1395-1406. doi: 10.1007/s10103-014-1531-6.

32. Rochkind S, Drory V, Alon M, Nissan M, Ouaknine GE. Laser phototherapy $(780 \mathrm{~nm})$, a new modality in treatment of long-term incomplete peripheral nerve injury: a randomized double-blind placebo-controlled study. Photomed Laser Surg. 2007;25(5): 436-42. doi: 10.1089/pho.2007.2093. 